\title{
The Used of Certificate of Land Rights on Proving in Land Disputes
}

\author{
Enny Agustina \\ Sekolah Tinggi Ilmu Hukum Pertiba, Indonesia \\ ennyagustinadua@yahoo.com
}

Submitted: Jun 3, 2021; Reviewed: Nov 3, 2021; Accepted: Nov 8, 2021

\begin{tabular}{l} 
Article's Info \\
\hline Keywords: $\quad$ Power of Evidence; \\
Certificates $\quad$ Land Rights; Land \\
Disputes.
\end{tabular}

DOI:

https://doi.org/10.25041/aelr.v2i2.2356

\section{Abstract}

\section{Abstract}

Based on Article 19 Paragraph (2) of Law No. 5 of 1960 and Article 32 of Government Regulation No. 24 of 1997, it is stated that in land registration, land certificates function as strong evidence. Whether a certificate can only prove property rights, and that evidence is in the judicial process so far. A literature study is conducted to obtain answers by exploring, discussing, and analyzing laws, research reports, and related expert views. The findings indicate that the National Land Agency issued the title certificate during the registration process. If there is a land without a certificate, it can be proven through witness testimony, prediction, confession and oath. A certificate with reliable and complete evidentiary power can only be accepted if there is no claim before the court. A claim against a certificate can be filed if there is a deficiency in its issuance.

\section{A. Introduction}

Article 19 paragraph (1) of Law No. 5 of 1960 concerning Basic Agrarian Regulations or Undang-Undang Pokok Agraria (UUPA) regulates legal assurance by the government, land registration is carried out throughout the territory of the Republic of Indonesia according to the provisions stipulated in a Government Regulation. The government has issued Government Regulation No. 10 of 1961 concerning Land Registration which was later revoked and replaced by Government Regulation No. 24 of 1997 concerning Land Registration.

Article 1 of Government Regulation No. 24 of 1997 states that land registration is a series of activities carried out by the government continuously and regularly. These activities include collecting, processing, bookkeeping and presentation and maintenance of physical data and 
juridical data, in the form of maps and lists of land parcels and apartment units. This parcel includes the provision of certificates of proof of rights for land parcels that already have rights and property rights on the apartment unit and certain rights that burden it.

Furthermore, in Article 3 letter a and Article 4 paragraph (1), it is stated that one of the objectives of carrying out land registration is to provide legal certainty and legal protection to holders of rights to a parcel of land, apartment units and other registered rights. The aim is to prove the holder of rights through a certificate of land rights.

Based on Article 19 paragraph (2) letter c of the LoGA and Article 32 paragraph (1) of Government Regulation 24 of 1997, a certificate proof of land rights acts as solid evidence. Because the data in the certificate includes data regarding the types of rights, the subject, and the location, boundaries, and extent, the certificate provides legal certainty for the data. From the above background, the problems are:

(1) Is it possible for uncertified land proven by other evidence?

(2) What is the strength of the certificate evidence that the Land Office has issued? Is it absolute? It will use normative legal approach with a legal inventory approach which collecting primary and secondary data, and also tertiary data. Qualitative analysis of research data, namely comparing or applying applicable laws and regulations, opinions of scholars (doctrine) and other legal theories. Deductive research conclusions, namely drawing conclusions starting from the general to the specific.

\section{B. Discussion}

\section{Evidence of Land Rights}

The theory in this study using land ownership based on customary law is that land is communal property or legal alliance (beschikkingsrecht). ${ }^{1}$ In this case, each member of the partnership can work the land by clearing the land first, and if they work on the land continuously, then the land can become individual property rights. ${ }^{2}$

Regarding the ownership of this customary land, Ter Haar as quoted by Kalo, explained as follows:

"Adat law gives prior rights to the person who used to put the prohibition sign or first cleared the land; if they do not carry out the logging and burning works according to the seasons, then someone else can pressure him to choose: continue to work or hand over the land to them. So this claim for ownership of property rights disappears completely when another fellow member wants it and presses him to choose one of the two options.".

According to Wignjodipoero, the right of fellowship on this land is also called the right of lordship or customary right, while Van Vollenhoven calls it bescikkingsrecht. ${ }^{4}$ Wignjodipoero further said that "This ulayat right in its basic form is a right rather than a partnership over the land inhabited, while the implementation is carried out or by the partnership itself or by the head of the partnership on behalf of the partnership." In this case, the definition of customary rights is stated as follows:

Ulayat rights are the rights of the adat law community to control land that is still a grove of forest within its territory for the benefit of the legal community. The benefit of outsiders of

\footnotetext{
${ }^{1}$ Adriaan Bedner and Yance Arizona, "Adat in Indonesian Land Law: A Promise for the Future or a Dead End?," The Asia Pacific Journal of Anthropology 20, no. 5 (2019): 416-34, https://doi.org/10.1080/14442213.2019.1670246.

${ }^{2}$ Boedi Harsono, Hukum Agraria Indonesia: Sejarah Pembentukan Undang-Undang Pokok Agraria, Isi, Dan Pelaksanaannya (Jakarta: Djambatan, 1997).

${ }^{3}$ Harsono.

${ }^{4}$ Tampil Anshari Siregar, Undang-Undang Pokok Agraria Dalam Bagan, 1st ed. (Medan: KSHM FH USU, 2004).
} 
the legal community by paying an acknowledgement fee is called or can be equated with recognition. ${ }^{5}$

Land Ownership In this study, one of the juridical grounds used is Article 33 Paragraph (3) of the 1945 Constitution which states that "Earth, water, and natural resources contained therein are controlled by the state and used for the greatest prosperity of the people". Regarding the land management of the Republic of Indonesia. Article 33 of the 1945 Constitution is the basis for the establishment of the Basic Agrarian Law Number 5 of 1960 concerning Basic Agrarian Regulations. Inside the Agrarian Law, the definition of property rights formulated in Article 20 of the LoGA is mentioned in paragraphs (1) and paragraph (2). These provisions regulate that property rights are hereditary, most vital and fulfilled rights, which people on land can own. Moreover, the property's rights can be transferred and transferred to other people. ${ }^{6}$

Evidence is needed to prove a person or a legal entity as the owner of a plot of land. In Article 19 paragraph (2) letter c of the UUPA and Article 32 paragraph (1) of Government Regulation No. 24 of 1997, it is determined that the certificate functions as evidence of land rights. The Regency/City Land Office issues certificates as evidence of land rights through a land registration process. Therefore, if a land parcel has not been registered, then the land parcel does not have a certificate. ${ }^{7}$

Every land parcel that exists throughout the territory of Indonesia should have been registered with the local Regency/Municipal Land Office so that land data can be fully and comprehensively available. Land registration will benefit all parties, government agencies themselves and individuals or the private sector, especially those who take legal actions or lay down legal relations on a plot of land. ${ }^{8}$ The Regency/City Land Office, as the institution authorized to carry out land registration, has started carrying out land registration in 1961 . The enactment of Government Regulation No. 10 of 1961 concerning Land Registration was later revoked and declared invalid by Government Regulation No. 24 of 1961 concerning Land Registration. One of the reasons for the Government Regulation No. 24 of 1997's issuance is that the legal provisions are used as the basis for implementing land registration. Land registrations are felt to be insufficient to provide the possibility for the implementation of land registration in a short time with satisfactory results. This is based on the fact that land registration, which was carried out based on Government Regulation No. 10 of 1961 for 35 years, has not been sufficient to provide satisfactory results. Fifty-five million land parcels meet the requirements to be registered. Approximately 16.3 million parcels have been registered. ${ }^{9}$

This fact can be understood that many parcels of land rights still do not yet have a certificate. The question is whether land parcels that have not been certified can be proven with anything other than certificates. The legal provisions do not mention certificates as the only means of proof of land rights. It must be understood that it is also applicable to provisions on proving rights in general as stipulated in the evidence law to prove land rights. ${ }^{10}$

Article $164 \mathrm{HIR} / 284 \mathrm{RBg}$ and Article 1866 of the Civil Code state that evidence in civil cases consists of; written evidence/letters, witness evidence, assumptions, confessions and

\footnotetext{
${ }^{5}$ Siregar.

${ }^{6}$ Article 20 of Law No. 5 of 1960 concerning Basic Agrarian Regulations

7 Joe Studwell, "Land for the People: The State and Agrarian Conflict in Indonesia," Bulletin of Indonesian Economic Studies 50, no. 2 (2014): 302-4, https://doi.org/10.1080/00074918.2014.938421.

${ }^{8}$ Ben White, "Marx and Chayanov at the Margins: Understanding Agrarian Change in Java," Journal of Peasant Studies 45, no. 5 (2018): 1108-26, https://doi.org/10.1080/03066150.2017.1419191.

${ }^{9}$ Government Regulation No. 24 of 1997 concerning Land Registration.

${ }^{10}$ Gunawan Widjaja and Kartini Muljadi, Hak-Hak Atas Tanah (Jakarta: Kencana, 2007).
} 
oaths. ${ }^{11}$ Written evidence or letters contain reading signs intended to pour out one's heart or convey thoughts and are used as evidence. ${ }^{12}$

In proving the existence of an event or the existence of something, first of all, written evidence is used. If there is no written evidence or insufficient, witness evidence is used. ${ }^{13}$ If the witness evidence is not sufficient, then presumptive evidence is used. If written evidence plus witness evidence and presumptive evidence are also not sufficient, then additional proof. If the evidence is not sufficient, then it is added with proof of oath. ${ }^{14}$ In the law of proof, there are three types of letters, namely authentic deeds, underhand deeds and non-deed letters. ${ }^{15}$ An authentic deed is a letter as evidence by a public official in power for that purpose. ${ }^{16}$

Based on Article 1 No. 20 Government Regulation No. 24 of 1997, a certificate is a certificate of proof of rights as referred to in Article 19 paragraph (2) letter $\mathrm{c}$ of the UUPA for land rights, management rights, waqf land, property rights to flat units and mortgage rights, respectively. -each has been recorded in the relevant land book. Technically, the limitation on certificates has been contained in Government Regulation No. 10 of 1961, which states that a certificate is a copy of a land book and a measuring document bound together and given a cover. ${ }^{17}$

The National Land Agency has the responsibilities on issuing the land certificate, which contains physical data and juridical data for a particular plot of land. Physical data regarding the location, boundaries and area of land parcels. At the same time, the juridical data relates to the subject of rights, the basis of rights and the imposition of land rights. The data is obtained from the certificate applicant and examined by the National Land Agency through the land registration process. Therefore, about the evidence in the civil court process as referred to in Article $164 \mathrm{HIR} / 284 \mathrm{RBg}$ and Article 1866 of the Civil Code, the certificate has the status of a letter of evidence that qualifies as an authentic deed. ${ }^{18}$

Based on the description above, it can be understood that if a parcel of land does not or does not have a certificate, it can be proven by other evidence as specified in the provisions of the legislation. The other evidence is regulated in Article $164 \mathrm{HIR} / 284 \mathrm{RBg}$, Article 1866 of the Civil Code, and Article 23 and Article 24 of Government Regulation No. 24 of 1997, which regulates proof of land rights to register land rights.

In Article 23 Government Regulation 24 of 1997, it is stated that to register land rights to land rights born after the enactment of the UUPA, it can be proven by;

(a) determination of the granting of rights (Decree on Granting of Rights) on state land or land with management rights from the authorized official,

(b) the deed of granting the Right to Use or Right to Build on the land with Ownership

Rights from Land Titles Registrar or Pejabat Pembuat Akta Tanah (PPAT)

(c) deed of contract,

(d) deed of separation of ownership of the apartment unit, dan (e) deed of granting a mortgage.

\footnotetext{
${ }^{11}$ Edward Lahiff, Saturnino M Borras, and Cristóbal Kay, "Market-Led Agrarian Reform: Policies, Performance and Prospects," Third World Quarterly 28, no. 8 (2007): 1417-36, https://doi.org/10.1080/01436590701637318.

12 Risnarto, "Dampak Sertipikasi Tanah Terhadap Pasar Tanah Dan Kepemilikan Tanah Skala Kecil," in Land and Household Economy 1970-2007 (Bogor: PSEKP and UNESCAP-CAPSA, 2007), 23, https://adoc.pub/5-dampakproyek-sertipikasi-tanah-terhadap-pasar-tanah-dan-k.html.

${ }^{13}$ Enny Agustina, "Pelaksanaan Pelayanan Publik Berkualitas Bagi Masyarakat," Jurnal Literasi Hukum 3, no. 2 (2019): 10-17, https://jurnal.untidar.ac.id/index.php/literasihukum/article/view/1977/pdf.

${ }^{14}$ Sudikno Mertokusumo, Hukum Acara Perdata Indonesia (Yogyakarta: Liberty, 2015).

15 Teguh Samudera, Hukum Pembuktian Dalam Acara Perdata (Bandung: Alumni, 1992).

${ }^{16}$ R. Wirjono Prodjodikoro, Hukum Acara Perdata Di Indonesia (Bandung: Sumur Bandung, 2015).

${ }^{17}$ Government Regulation No. 10 of 1961.

${ }^{18}$ Abdulkadir Muhammad, Hukum Acara Perdata, 8th ed. (Bandung: Citra Aditya Bhakti, 2008).
} 
It can be further explained that concerning land rights that occur based on the determination of the granting of rights from the authorized official, the registration of rights is a condition for the birth of the rights to the land in question. Because the evidence of rights issued in the land registration process is only a certificate, it must also be understood that land rights born based on the determination of the granting of rights from the authorized official can only be proven by a certificate. This is different from land rights that are born based on the determination of the granting of rights from the authorized official.

Meanwhile, land rights that existed before the UUPA enactment can be converted into one of the land rights known in the UUPA (or better known as land rights born under the provisions of the conversion of the UUPA). Based on Article 24 paragraph (1) of Government Regulation No. 24 of 1997 that to register rights, evidenced through evidence regarding the existence of such rights in the form of written evidence, witness statements and/or statements in question whose truth levels are considered sufficient for registration of rights. ${ }^{19}$

In the Elucidation of Article 24 paragraph (1) of Government Regulations/1997, it is stated that the written evidence can be in the form of, among others: (a) eigendom rights deed issued based on Overcrijvings Ordonnantie (Stb. 1834-27); (b) proof of ownership rights issued under the Swapraja Regulation; (c) a deed of transfer of rights made under the hand which is affixed with a testimony by the Customary Head or Village/Kelurahan Head made before the enactment of Government Regulation No. 24 of 1997; (d) Minutes of the auction made by an authorized auction official whose land has not been recorded.

Furthermore, in Article 24 paragraph (2) of Government Regulation No. 24 of 1997, it is stated: If the evidence is not or is no longer completely available, the evidence as referred to in paragraph (1), bookkeeping of rights can be carried out based on the fact of physical possession of the land parcel in question for 20 (twenty) years or more in a row by the applicant for registration and his predecessor, with provisions of:

a. the control is carried out openly by the person concerned as the right to the land, and is strengthened trustworthy person's testimony;

b. the control both before and during the announcement, as referred to in Article 26, is not disputed by the adat law community or the village concerned or other parties. ${ }^{20}$

Based on the rules contained in Government Regulation No. 24 of 1997, it can be understood that to prove land rights for land registration purposes, it can be done with letters, witness statements, and statements in question. Of course, this provision can be treated mutatis mutandis to the proof of land rights in the judicial process. ${ }^{21}$

\section{Certificate of Evidence's Strength}

One of the functions of the deed is as a means of proof. The deed is divided into three evidentiary powers. These powers are (1) the power of outward proof, the power of formal proof and the strength of material proof. (2) The strength of birth evidence is evidence-based on birth circumstances considered (accepted) as a deed and must be treated as a deed as long as the opposite is not proven. (3) The strength of formal evidence is based on the deed signer's necessities. Meanwhile, the material evidence's strength is based on the signer's stated legal events stated in the deed have occurred.

\footnotetext{
${ }^{19}$ Mohammad Taufik Makarao, Pokok-Pokok Hukum Acara Perdata (Jakarta: Rineka Cipta, 2004).

${ }^{20}$ Article 26 of Government Regulation No. 24/1997 states that before the data on a plot of land is recorded in the Land Office's registers. The land data must be announced for a certain period at the Land Office. The Village/Kelurahan Office or other places deemed necessary to provide an opportunity for interested parties to raise objections.

${ }^{21}$ Muhammad Yahya Harahap, Hukum Acara Perdata: Tentang: Gugatan, Persidangan, Penyitaan, Pembuktian, Dan Putusan Pengadilan (Jakarta: Sinar Grafika, 2011).
} 
The authentic certificate has the power of birth, formal and material proof, and is based on Article 165 HIR. The authentic deed has perfect power. This means a statement in the deed must be accepted as valid as long as no party can prove otherwise. ${ }^{22}$

Regarding the strength of proof of land rights certificates, there is a separate term in the provisions of the land legislation as stipulated in Article 19 paragraph (2) letter $\mathrm{c}$ of the UUPA, which states that land registration activities include; "Provision of letters of proof of rights, which act as strong evidence". Likewise, Article 32 paragraph (1) Government Regulation 24/1997 states; "certificate is a certificate of proof of rights that applies as a strong means of proof regarding the physical data and juridical data contained in it, as long as the physical data and juridical data are in accordance with the data contained in the letter of measurement and the book of land rights in question".

Furthermore, in the Elucidation of Article 32 paragraph (1)) of Government Regulation 24/1997. It is stated that a certificate is a vital sign of evidence, in the sense that as long as it cannot be proven otherwise, the physical data and juridical data contained therein must be accepted as correct data. ${ }^{23}$

Therefore, as long as it cannot be proven otherwise, the physical data and juridical data listed in the certificate must be accepted as correct data, both in carrying out daily legal actions and in litigation in court. ${ }^{24}$

In connection with this, it can be understood that the certificate does not have absolute power of evidence because it is still possible to be declared null and void or declared to have no legal force through a court decision. Interested parties can file a lawsuit to ask the court to decide that a land rights certificate has no legal force.

Based on Government Regulation No. 10 of 1961, any time a person or legal entity can file a lawsuit against a certificate. However, based on Government Regulation No. 24 of 1997, which has also revoked and declared the Government Regulation No. 10 of 1961 invalid, that a lawsuit against a certificate can no longer be filed if a particular time has passed and has met the requirements as stipulated in Article 32 paragraph (2).

Article 32 paragraph (2) of Government Regulation No. 24 of 1997 states: If a land parcel has been legally issued in the name of the person or legal entity who acquired the land, the other party can no longer demand the implementation of the right if within 5 (five) years from the issuance of the certificate. The land certificate does not file a written objection to the certificate holder and the Head of the Land Office concerned. It also does not file a lawsuit to the court regarding possession of the land or the issuance of the certificate.

In the Elucidation of Article 32 paragraph (2), it is further explained that the provision aims at one party to stick to the negative publication system and, on the other hand, to provide legal certainty to parties in a balanced manner. The party has in reasonable faith control of a plot of land and is registered as a right-holder in the land book, with a certificate as proof. The weakness of the negative publication system is that the party whose name is listed as the right holder in the land book and certificate always faces the possibility of a lawsuit from another party who feels he owns the land. Because Indonesia's land law is based on customary law, use institutions "rechtsverwerking" to overcome these weaknesses. In customary law, if a person has left his land uncultivated for some time, then the land is worked on by someone else who

\footnotetext{
22 Enny Agustina, "IMPLEMENTATION OF THE REGIONAL GOVERNMENT AND ADMINISTRATIVE SANCTIONS IN INDONESIAN REGIONAL REGULATIONS," Humanities \& Social Sciences Reviews 8, no. 1 (2020): 177-82, https://doi.org/10.18510/hssr.2020.8125.

${ }^{23}$ Jamila Hussain, "More Than One Law for All: Legal Pluralism in Southeast Asia," Democracy and Security 7 , no. 4 (2011): 374-89, https://doi.org/10.1080/17419166.2011.617621.

${ }^{24}$ Irawan Soerodjo, Kepastian Hukum Hak Atas Tanah Di Indonesia (Surabaya: Arkola, 2003).
} 
obtained it in good faith, then his right to claim the land is lost, which in the provisions of the land law is called the abolition of land rights due to neglect. ${ }^{25}$

Based on these provisions, it can be understood that the 5 (five) year time limit applies if it fulfils 3 (three) requirements, namely; (1) The 5 (five) year time limit applies if it fulfils 3 (three) requirements. For example, one of the stages of land registration implementation is an announcement of land data researched before the bookkeeping of land rights is carried out. If the announcement is not made or is carried out not under the rules or deviates from the purpose of the announcement, it can be categorized as a legal defect in the certification process. (2) land tenure by the applicant or his successor is carried out in good faith. (3) the land is controlled by the applicant. This means that legal control is not enough. Thus, if the three requirements are not met cumulatively, the 5 (five) year time limit cannot be applied.

Because the regulation is still in the form of a Government Regulation, judge in the application of Article 32 paragraph (2) Government Regulation 24 of 1997 to concrete cases that will consider the fulfilment of the conditions for its application as well as the application of the "rechtsverwerking" institution on customary lands. The judge weighs the disputing parties' interest, and in the context of reforming the national land law, this provision needs to be regulated in the form of a law. ${ }^{26}$

Although the court has the authority to decide the invalidity or declare that it has no legal force against a certificate, the court is not authorized to cancel the certificate in question. The statement of a certificate has no legal force, and the cancellation of a certificate are two different things, although they are related. The difference in principle lies in the authority and legal consequences. The statement that a certificate has no legal force is the court's authority. In contrast, the cancellation of the certificate is the authority of the National Land Agency or Badan Pertanahan Nasional (BPN). ${ }^{27}$

Based on Article 3 of Presidential Regulation No. 10 of 2006 concerning the National Land Agency and Article 13 of Regulation of the State Minister of Agrarian Affairs/Head of the National Land Agency No. 3 of 1999 concerning Delegation of Authority for Granting and Cancellation of Decisions on the Granting of State Land Rights, that the State Minister of Agrarian Affairs/Head of BPN has the authority to cancel the decision to grant land rights.

Furthermore, Article 104 of the Regulation of the Minister of State for Agrarian Affairs/Head of BPN No. 9 of 1999 concerning Procedures for Granting and Canceling State Land Rights and Management Rights. It is stated that the cancellation of the decision to grant and certificate of land rights is issued for two reasons: (1) because there is an administrative, legal defect in the issuance of the decision to grant and/or certificate of land rights or (2) for carrying out a court decision that has obtained permanent legal force.

To cancel a certificate based on a court decision, the interested party must apply for the Head of BPN. Problems arise if the cancellation request is not granted whether the subject of the rights listed in his name is still entitled to the land has been declared to have no legal force by BPN. This has the potential for multiple interpretations, depending on the understanding of the position of the court decision and Ministerial Regulation/Head of BPN's position in the Indonesian legal system. Some believe that a certificate declared to have no legal force by the court even though the BPN has not cancelled it causes the certificate to have lost its power as

25 Enny Agustina, "Legal Malfunctions and Efforts in Reconstructing the Legal System Service: A State Administrative Law Perspective," Jurnal Dinamika Hukum 18, no. 3 (2018): 357-64, https://doi.org/10.20884/1.jdh.2018.18.3.2117.

26 Harsono, Hukum Agraria Indonesia: Sejarah Pembentukan Undang-Undang Pokok Agraria, Isi, Dan Pelaksanaannya.

${ }^{27}$ Hilaire Tagnan, "Legal Pluralism and Land Administration in West Sumatra: The Implementation of the Regulations of Both Local and Nagari Governments on Communal Land Tenure," The Journal of Legal Pluralism and Unofficial Law 47, no. 2 (2015): 312-23, https://doi.org/10.1080/07329113.2015.1072386. 
an authentic deed. Thus, since the decision was read, the certificate in question can no longer be used as a basis for carrying out legal actions. ${ }^{28}$ Therefore, it should be stated in the laws and regulations explicitly that the cancellation of land rights and certificates based on court decisions is purely administrative. Moreover, these land parcels are declared null and void and have no force in force by the court.

\section{Conclusion}

1. Certificates are the primary evidence of land rights but are not the only evidence. The absence of a certificate does not in itself mean the absence of a person's right to a plot of land. To prove ownership rights to a plot of land can be proven by other evidence and evidence that can be used in civil court proceedings in general as specified in HIR/RBg and the Civil Code.

2. The certificate does not have absolute power because it can still be declared to have no legal force if proven otherwise through a judicial process. In UUPA and Government Regulation 24 of 1997, it is stated that a certificate has strong evidence. It must be accepted as valid as long as it cannot be proven untruth in a judicial process. Claims for land rights claim and cancellation can be filed by interested parties even though 5 (five) years have passed since the issuance of the certificates. This situation provides that it can prove a legal defect in the certificate issuance process, the acquisition of land rights is not in good faith and/or the land for which the rights are applied is not controlled.

\section{Bibiliography}

\section{A. Journal}

Agustina, Enny. "Implementation Of The Regional Government And Administrative Sanctions In Indonesian Regional Regulations." Humanities \& Social Sciences Reviews 8, no. 1 (2020): 177-82. https://doi.org/10.18510/hssr.2020.8125.

— . "Legal Malfunctions and Efforts in Reconstructing the Legal System Service: A State Administrative Law Perspective." Jurnal Dinamika Hukum 18, no. 3 (2018): 357-64. https://doi.org/10.20884/1.jdh.2018.18.3.2117.

\section{- "PELAKSANAAN PELAYANAN PUBLIK BERKUALITAS BAGI} MASYARAKAT." Jurnal Literasi Hukum 3, no. 2 (2019): 10-17. https://jurnal.untidar.ac.id/index.php/literasihukum/article/view/1977/pdf.

Bedner, Adriaan, and Yance Arizona. "Adat in Indonesian Land Law: A Promise for the Future or a Dead End?" The Asia Pacific Journal of Anthropology 20, no. 5 (2019): 416-34. https://doi.org/10.1080/14442213.2019.1670246.

Hussain, Jamila. "More Than One Law for All: Legal Pluralism in Southeast Asia.” Democracy and Security 7, no. 4 (2011): 374-89. https://doi.org/10.1080/17419166.2011.617621.

Lahiff, Edward, Saturnino M Borras, and Cristóbal Kay. "Market-Led Agrarian Reform: Policies, Performance and Prospects." Third World Quarterly 28, no. 8 (2007): 1417-36. https://doi.org/10.1080/01436590701637318.

Studwell, Joe. "Land for the People: The State and Agrarian Conflict in Indonesia." Bulletin of Indonesian Economic Studies 50, no. 2 (2014): 302-4. https://doi.org/10.1080/00074918.2014.938421.

Tagnan, Hilaire. "Legal Pluralism and Land Administration in West Sumatra: The Implementation of the Regulations of Both Local and Nagari Governments on Communal

\footnotetext{
28 Maya Santika, "Kekuatan Hukum Sertipikat Hak Atas Tanah Yang Telah Dinyatakan Tidak Mempunyai Kekuatan Hukum Oleh Pengadilan” (Universitas Syiah Kuala, 2010).
} 
Land Tenure.” The Journal of Legal Pluralism and Unofficial Law 47, no. 2 (2015): 31223. https://doi.org/10.1080/07329113.2015.1072386.

White, Ben. "Marx and Chayanov at the Margins: Understanding Agrarian Change in Java." Journal of Peasant Studies 45, no. 5 (2018): 1108-26. https://doi.org/10.1080/03066150.2017.1419191.

\section{B. Books}

Harahap, Muhammad Yahya. Hukum Acara Perdata: Tentang: Gugatan, Persidangan, Penyitaan, Pembuktian, Dan Putusan Pengadilan. Jakarta: Sinar Grafika, 2011.

Harsono, Boedi. Hukum Agraria Indonesia: Sejarah Pembentukan Undang-Undang Pokok Agraria, Isi, Dan Pelaksanaannya. Jakarta: Djambatan, 1997.

Makarao, Mohammad Taufik. Pokok-Pokok Hukum Acara Perdata. Jakarta: Rineka Cipta, 2004.

Mertokusumo, Sudikno. Hukum Acara Perdata Indonesia. Yogyakarta: Liberty, 2015.

Muhammad, Abdulkadir. Hukum Acara Perdata. 8th ed. Bandung: Citra Aditya Bhakti, 2008.

Prodjodikoro, R. Wirjono. Hukum Acara Perdata Di Indonesia. Bandung: Sumur Bandung, 2015.

Risnarto. "Dampak Sertipikasi Tanah Terhadap Pasar Tanah Dan Kepemilikan Tanah Skala Kecil." In Land and Household Economy 1970-2007, 23. Bogor: PSEKP and UNESCAPCAPSA, 2007. https://adoc.pub/5-dampak-proyek-sertipikasi-tanah-terhadap-pasartanah-dan-k.html.

Samudera, Teguh. Hukum Pembuktian Dalam Acara Perdata. Bandung: Alumni, 1992.

Santika, Maya. "Kekuatan Hukum Sertipikat Hak Atas Tanah Yang Telah Dinyatakan Tidak Mempunyai Kekuatan Hukum Oleh Pengadilan.” Universitas Syiah Kuala, 2010.

Siregar, Tampil Anshari. Undang-Undang Pokok Agraria Dalam Bagan. 1st ed. Medan: KSHM FH USU, 2004.

Soerodjo, Irawan. Kepastian Hukum Hak Atas Tanah Di Indonesia. Surabaya: Arkola, 2003. Widjaja, Gunawan, and Kartini Muljadi. Hak-Hak Atas Tanah. Jakarta: Kencana, 2007.

\section{Regulations}

1945 Indonesia Constitution

Law No. 5 of 1960 concerning Agrarian Principles

Government Regulation No. 24 of 1997 concerning Land Registration 
